\title{
MICROBIOLOGIA BUCAL EM PACIENTES IDOSOS
}

Cintia Ligia OLICHEVES; Natalia Medella SANTANA; Taryn Torres Rosa CAPOBIANCO; Thamielem Pereira LIVI; Maria Helena TOMMASI

A composição da flora bacteriana em pacientes idosos depende principalmente das condições endógenas, podendo ser alterada por diversos fatores como ausência de dentes, utilização de próteses totais, deficiências imunológicas, hiposalivação, utilização de medicamentos e doenças crônicas. Essas mudanças na flora bacteriana podem ser um dos fatores desencadeantes de patologias bucais, dentre elas, infecções oportunistas, periodontites e cáries (ROSA, 1995). Na cavidade bucal do idoso o biofilme dental forma-se mais rapidamente, provavelmente devido a mudanças na composição da dieta e diminuição na destreza manual e acuidade visual, o que torna o controle mecânico da placa menos eficiente (MOURA, 2004). Com o envelhecimento, a mucosa bucal torna-se mais delgada, e, portanto, mais vulnerável para o aparecimento da candidose (BELLO, 1999). Outros fatores como a falta de conhecimento dessa população também pode influenciar no processo saúde/doença (MOIAMAZ, 2004). Através de uma revisão de literatura, este artigo tem por objetivo relacionar a composição da flora bacteriana com as alterações causadas pelo envelhecimento e as manifestações das patologias bucais, visto que o conhecimento dessas interações é extremamente importante para o diagnóstico das reais necessidades e prioridades do idoso, bem como para o delineamento do plano de tratamento. 